\title{
Reflections of nurses in search of a theoretical framework for maternity care
}

\author{
Reflexões de enfermeiras na busca do referencial teórico para assistência na maternidade \\ Reflexiones de enfermeras en búsqueda del referencial teórico de atención en la maternidad
}

\section{Rosiane da Rosa', Roberta Costa', Ana Izabel Jatobá de Souza', Margarete Maria Lima', Dulcinéia Ghizoni Schneider', Evanguelia Kotzias Atherino dos Santos'}

' Universidade Federal de Santa Catarina. Florianópolis, Santa Catarina, Brazil.

How to cite this article:

Rosa R, Costa R, Souza AIJ, Lima MM, Schneider DG, Santos EKA. Reflections of nurses in search of a theoretical framework for maternity care. Rev Bras Enferm [Internet]. 2018;71(Suppl 3):1351-7. [Thematic Issue: Health of woman and child] DOI: http://dx.doi.org/10.1590/0034-7167-2016-0525

\section{Submission: 11-10-2016 Approval: 10-01-2017}

\section{ABSTRACT}

Objective: To define a theoretical framework to guide the systematization of nursing care in a maternity unit in the South of Brazil. Method: This was the preliminary stage of a qualitative methodological study, based on an educational activity and the assumptions of Paulo Freire, involving 15 nurses, between August and November 2015. The aim of data analysis was to identify emerging themes. Results: The following themes emerged: knowledge of nurses about nursing theories; barriers to implementing and systematizing nursing care; the importance of a framework to guide practice and; educational activities as opportunities to systematize nursing care. Conclusion: The discussion process involved in establishing the theoretical framework enabled reflections about nursing practices, reinforcing the importance of theoretical frameworks to guide work processes and enhance quality of care.

Descriptors: Nursing Theory; Maternity Wards; Maternal-Child Nursing; Nursing; Continuing Education.

\section{RESUMO}

Objetivo: definir o referencial teórico para sustentar a implantação da sistematização da assistência de enfermagem em uma maternidade do sul do Brasil. Método: trata-se da etapa preliminar de um estudo metodológico, com abordagem qualitativa dos dados, realizada a partir de uma prática educativa, guiada pelos pressupostos de Paulo Freire, com 15 enfermeiras, no período de agosto a novembro de 2015. A análise de dados buscou identificar os temas emergentes. Resultados: como temas emergentes foram elencados: Conhecimento das enfermeiras sobre Teorias de Enfermagem; Dificuldades para implementação da sistematização da assistência de enfermagem; Importância do referencial para subsidiar a prática e; e A prática educativa como possibilidade para efetivação da sistematização da assistência de enfermagem. Conclusão: o processo de discussão para a obtenção do referencial teórico permitiu reflexões sobre a prática, reforçando a importância de um referencial teórico para guiar o processo de trabalho e fortalecimento da qualidade da assistência.

Descritores: Teoria de Enfermagem; Maternidades; Enfermagem Materno-Infantil; Enfermagem; Educação Continuada.

\section{RESUMEN}

Objetivo: Definir el referencial teórico de respaldo para implantar la sistematización de la atención de enfermería en maternidad del sur de Brasil. Método: Etapa preliminar de estudio metodológico, de abordaje cualitativo de datos, realizado a partir de práctica educativa guiada por los supuestos de Paulo Freire, con 15 enfermeras, entre agosto y noviembre de 2015 . El análisis de datos buscó identificar los temas emergentes. Resultados: Como temas emergentes fueron hallados: Conocimiento de las enfermeras sobre Teorías de Enfermería; Dificultades para implementación de sistematización de la atención de enfermería; Importancia del referencial para respaldar la práctica; y La práctica educativa como posibilidad de concreción de la sistematización de la atención de enfermería. Conclusión: El proceso de discusión para obtener el referencial teórico permitió reflexiones sobre la práctica, reforzando la importancia de un referencial teórico para orientar su proceso de trabajo y la optimización de la calidad de la atención.

Descriptores: Teoría de Enfermería; Maternidades; Enfermería Maternoinfantil; Enfermería; Educación Continua. 


\section{INTRODUCTION}

The systematization of nursing care $(\mathrm{SNC})$ is used by nursing professionals to plan, organize and guide their practice. It is put into operation through the creation of nursing processes (NP) which are tailored to individual patients, improved nursing records, and humanization of care. When scientifically based, NPs can be determinant of quality of care ${ }^{(1)}$.

The effective implementation of SNC depends on the adoption of theoretical frameworks aligned with the reality of assisted populations and the organizational environment. Nursing theories contribute by helping professionals understand specific work realities, favoring reflection and critical thinking, the inclusion of scientific elements in their analysis, supporting the definition of nursing roles, and contributing to the production of knowledge ${ }^{(2)}$.

According to Resolution no. 358/2009 of the Brazilian Federal Council of Nursing (COFEN), NPs should be grounded in theoretical frameworks that guide data collection, nursing diagnoses, and nursing action plans, in addition to providing a basis for assessing nursing outcomes ${ }^{(3)}$.

A literature search was conducted in the SciELO (Scientific Electronic Library Online) and LILACS (Latin American and Caribbean Health Sciences Literature) databases, using the following descriptors: "nursing processes," "newborns," "obstetrics," "nursing theory," "neonatal intensive care units," and "maternity wards," limited to the period ranging from 1990 to 2015. Only three dissertations and four articles were found describing the theoretical frameworks used to guide maternalchild care practices.

In addition to the theoretical frameworks for implementing $\mathrm{SNC}$, ongoing education is also a necessity. This raises professional awareness about the importance of SNC and of assessing its implementation, adapted to the local realities of services ${ }^{(4)}$.

However, even though SNC is a legal obligation and contributes to quality of care, there are still many barriers to its implementation. A study conducted in three hospitals in a municipality in the south of the Brazilian state of Minas Gerais showed that there are more barriers than gateways to operationalizing SNC, such as lack of systematic and personalized implementation of SNC, nursing records relative to SNC, printed materials and protocols, nursing staff, capacity-building processes, adequate shift handover environment, and nursing records ${ }^{(5)}$.

Other barriers to implementing SNC are: lack of professional experience, lack of recognition felt by nurses, and the greater importance placed by many professionals on technical issues rather than scientific ones ${ }^{(6)}$.

A study conducted in South America showed similar difficulties in implementing NP, such as difficulty formulating $\mathrm{NP}$, teacher training, resistance of physicians and little nursing presence in management ${ }^{(7)}$.

Thus, even though the COFEN has recommended SNC for the last 14 years and that several studies have shown its association with improved quality of care, it has yet to be operationalized in many institutions ${ }^{(1-2,5-6)}$, as is the case of the institution investigated in the present study.
The first step to ensuring that the implementation of SNC is put into practice is to define a theoretical framework to guide nursing. To choose an adequate framework, it is essential to establish a dialogue with all those involved, so that they can critically think about their actions and reality, seeking to establish a relationship between theory and practice. During collective dialogue, subjects find themselves in the search for paths to transform their reality, permeated by the action-reflectionaction process and the possibility of creating and recreating ${ }^{(8)}$.

In light of the above, the following research question was formulated: According to the perception of the nursing staff, what is the most adequate theoretical framework to guide the implementation of SNC in a public maternity ward in the South of Brazil?

\section{OBJECTIVE}

To define a theoretical framework to guide the implementation of systematization of nursing care in a maternity unit in the South of Brazil.

The present investigation can represent a contribution to the studied institution, because the choice of a theoretical framework can awaken the interest of maternity nurses in implementing SNC in the units.

\section{METHOD}

\section{Ethical aspects}

The present study abided by Resolution 466/12 pf the Brazilian National Council of Health, ensuring anonymity, voluntary participation and the right to withdraw from the study at any point ${ }^{(9)}$. Participants signed informed consent forms, and photo and recording release forms. The study was approved by the institution as well as the research ethics committee of the investigated institution. To ensure anonymity, participants were identified with the letter $\mathrm{N}$ (nurse) followed by sequential numbers (for example, N1, N2,..,N15).

\section{Type of study}

This was a methodological study whose final aim was to develop a prototype of SNC software in a neonatal unit. The present paper presents the first step of the study, a qualitative approach, in which an educational practice was developed with the nurses of this unit.

The educational practice was based on the assumptions of Paulo Freire's problematization methodology, which considers that individuals, based on their social, historical and cultural reality, can become aware of the role they play in society and of what oppresses them, leading them to action and reflection about their reality in order to modify it. In this process, participants are encouraged to share knowledge and experiences, using their own reality as a starting point and the situations that they consider to be problematic ${ }^{(10)}$.

\section{Study location and participants}

The study was developed with 15 nurses working at a public maternity unit in the South of Brazil, which is $100 \%$ linked to the Unified Health System and a tertiary reference center 
in obstetric and neonatal care in the state of Santa Catarina. Inclusion criteria for selecting nurses were: being part of the nursing staff and working in the institution, and exclusion criteria were: nurses on vacation, on leave of absences, and undergoing health treatments.

\section{Data collection and organization}

Data collection was based on different strategies: document search, meetings with the nursing staff, and discussions during the nurses' daily work routine.

First, between August and September 2015, the researchers consulted all existing materials about prior initiatives to SNC in the maternity unit. To this end, the institution's nurse manager was contacted to investigate the documents and tools created at different points of the unit's history, in attempts to implement SNC. However, no documents of this sort were found. Thus, the next step was to contact the nurses who had the longest history working in the institution, and one of them still had the documents created by the study group responsible for developing the institution's care methodology project in 1996 and 2001.

Next, an educational activity was conducted by the main researcher, between October and November 2015, with 15 staff nurses. The purpose of the first encounter with participants was to present the issue to be addressed during the educational practice, i.e., the lack of a theoretical framework to guide the implementation of SNC in the institutions. In this meeting, there was a brief presentation of the study "Systematization of Nursing Care in Neonatal Units: developing a prototype-software." Afterwards, the researchers explained the importance of a theoretical framework and presented previous attempts at implementing SNC in the maternity unit, providing participants with the documents that were recovered in the documental phase of the study. Next, nurses were asked to share their knowledge about nursing theories in 3 groups of 5 nurses. After the group presentations, the researcher explained the theoretical frameworks found in the literature in the field of maternal-child care.

After the first meeting, nurses were encouraged to promote discussions about the theme with their work teams, with the goal of defining which theoretical framework was best suited to the reality of their work environment. They agreed to record the group's decision and leave it to the nurse management. This strategy was developed with the goal of involving the institution's entire nursing team in reflecting on the topic

The second meeting consisted of a dialogued lecture about the SNC by an expert in the field, followed by a presentation given by the nurses about the theories chosen to guide the implementation of the SNC. To end the activity, a video about teamwork and planning was presented, after which the participants received an assessment tool. Each meeting lasted an average of three hours and was recorded through audio, photographs, and written assessments of the activities.

\section{Data analysis}

Data analysis was conducted in three phases: Phase 1 Data collection and organization. This phase consisted of recordings and transcriptions; Phase 2 - Coding. Similar themes were coded in groups; and Phase 3 - Identifying emerging themes. Four emerging themes were identified ${ }^{(11-12)}$.

\section{RESULTS}

To help define the theoretical framework, an initial document search was conducted to learn more about the history of movements to implement SNC in the institution, and based the discussion with nurses according to their own reality. The researchers found tools developed in 1996 by a study group created to implement an institutional care methodology, obstetric nursing history, and nursing prescriptions to puerperal women. These instruments were in checklist form and were based on the theory of basic human needs. According to the reports of some nurses, these tools were not put into practice. Only in 2001, when nurse Evanguelia Kotzias Atherino dos Santos took over as general manager of the maternity unit, discussions started up again. However, they were not put into action and little progress was made at the time.

Based on a search in the literature about the theme and the results of the document research, an education activity was carried out with the maternity nurses, based on the problematizing pedagogy of Paulo Freire. The data gathered from this activity were analyzed in search of emerging themes, with the goal of indicating the path taken to define the theoretical framework.

\section{Theme 1: Knowledge of nurses about nursing theory}

Regarding the concept/definition of nursing theory, the nurses expressed that:

They are concepts and assumptions used to organize and guide nursing care. (N1, N2, N3, N4, N5)

Theories guide nursing care. (N6, N7, N8, N9, N10)

Theories are knowledge that guides nursing practice. (N11, N12, N13, N14, N15)

The nurses displayed knowledge of different theories, such as Orem's self-care theory, Roy's adaptation theory, Lininger's transcultural theory, the theory of basic human needs by Wanda de Aguiar Horta, the humanistic theory by Paterson and Zderad, the environmental theory of Florence, and Peplau's theory of interpersonal relationships. However, they had been exposed to such theories during their undergraduate studies, and had not had any further exposure in their practice at the institution.

Roy's theory could be used anywhere in the unit, it's very interesting because it addresses the fact that parents are the ones adapting because their child is being born, the child is adapting, part of the woman's life dies, and she has to adapt to her new situation and family, it's a very encompassing theory. (N12)

All the nurses are familiar with Wanda Horta's theory, which is the theory of basic human needs, both in our undergraduate program when studying nursing process and both here at the institution in the past when they studied to apply the theory, which was not implemented, but it was studied by a group of nurses here. (E14) 
Theme 2: Difficulties in implementing the Systematization of Nursing Care

The professionals commented about the attempts to implement NCS in the institution, showing commitment and pointing to the difficulties faced in practice:

We're trying, the important thing is not to quit. (N12)

When we tried implementing SNC, we worked hard, studied a lot, giving references to management and we chose Wanda's framework. If it died at the time, it was because there were no nurses 24 hours, so there would have been no continuity if it had been implemented.

We tried twice to implement SNC, but it was not possible albeit all our efforts. We generally had one nurse to cover the entire maternity unit, making it impossible to systematize care. (Researcher's field diary)

\section{Theme 3: The importance of frameworks to guide practice}

As a theorist, it is important to realize that to apply the theory, we need to study, study, and make it a part of everybody's practice. Everyone's familiarity with this theory makes it easier. It's complex, but it's something to consider carefully. (N12)

Orem's theory is used in the milk bank, even though it is not completely systematized. Why Orem? Because she touches on self-care, and the women who come here with engorged breasts need to continue self-care at home. Continuity of care occurs at home, adapting to the sector's practice. (N13)

At this one hospital where SNC is being implemented, they used Travelbee's theory, it's wonderful, everything is set up in the system. At another hospital, they used the basic human needs theory, with everything set up in the system. It's incredible to see it in practice, it makes our eyes sparkle... To see everything you ever dreamed of doing, to see the difference it'll make in the institution, and how it will safeguard professionals, its importance to the team as a whole, so nursing can show its work. It's amazing. (N11)

Theme 4: The educational activity as a possibility for implementing the systematization of nursing care

I think this initiative of committing to the theme of implementing SNC in the institution was very important. (N3)

I like how clearly and easily the topic was addressed, which can make it possible to implement SNC this time. (N6)

I would like more meetings so we can construct the instruments that would be used. (N8)

I liked meeting with nurses from different sectors to discuss and reflect about systematization. (N1)

Thus, after the nurses took the discussion to their different units, the nursing teams elected the theory of basic human needs (Figure 1).

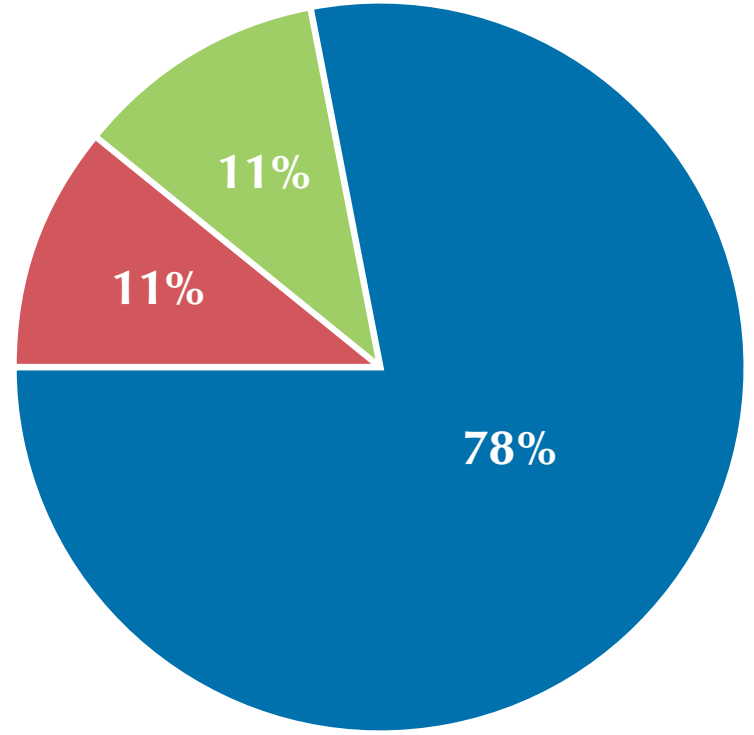

N.H.B. Theory

Orem Theory

King Theory

Figure 1 - Opinion of nurses about the theoretical framework to be adopted, Florianópolis, Santa Catarina, Brazil, 2015

Last, special mention goes to the request made by the nurses to continue the meetings to discuss how to apply the theoretical framework to maternity practices and how to develop NP steps in each unit.

\section{DISCUSSION}

The results show that the nurses were knowledgeable about the definition of nursing theory and were familiar with some theories and their importance in nursing practice. The nurses understood SNC as a work method that is based on theoretical models applied to practice, through nursing processes, resulting in a work methodology that systematizes work actions and organization $^{(13)}$.

In another study, nursing theories were shown to be essential to the construction of knowledge and professional practice, because they help "guide clinical nursing models and enable professionals to describe and explain aspects of their care reality, contributing to the development of the theory, research, and practice triad in the field"(14).

Nursing theories are used to understand and give meaning to professional practice, ensuring that it is based on the personal experiences scientific assumptions of each theorist ${ }^{(15)}$. They are also essential to describe, predict and explain the phenomena by way of investigation, providing greater clarity and using consistent definitions to improve care ${ }^{(16)}$. Thus, reciprocity is established between nursing theory and actions to structure professional practice ${ }^{(17)}$.

"Nursing theories help understand reality, favoring reflection and critique, preventing phenomena from becoming naturalized 
or trivialized, using scientific elements to understand and analyze reality"(2).

It is worth highlighting the different attempts to implement $\mathrm{SNC}$ at the institution and the nurse's involvement despite their day-to-day difficulties. This reality is not unique to this institution; other studies have shown challenges in the implementation of SNC such as professionals' lack of time, reduced nursing staff, work overload, high patient demand, team unpreparedness, depreciation by other professionals, and lack of interest and support from the institution ${ }^{(6-7,18-19)}$.

The results of this study present a discussion about the importance of SNC. The nurses recognized that SNC is a proposal to improve the quality of care and that results in practices centered on the individual needs of patients. Moreover, it was considered a tool that helps deepen knowledge, grant professional autonomy, and enable continuity of care, resulting in greater professional recognition ${ }^{(13)}$. The absence of SNC directly results in lack of visibility and recognition of nursing, creating obstacles in the evaluation of nursing practice and advances within the profession ${ }^{(20)}$.

To efficiently implement SNC, it should be guided by a nursing theory that is aligned with the reality of patients and the organizational environment ${ }^{(2)}$.

Even though the benefits of implementing SNC have been demonstrated in the scientific literature, many institutions still do not have theoretical frameworks and nurses do not work in a systematic manner based on nursing theories.

The nurses' choice of the basic human needs theory is likely because they are more familiar with it, having been exposed to the theory during their undergraduate training. "For nursing care to be adequate and individualized, NP must be adopted, based on a specific theory that all care professionals are cognizant"(21).

Wanda de Aguiar Horta's theory is the most recognized and utilized theoretical model in Brazil. The theory focuses on basic human needs, wherein their elements "explain, substantiate, and give meaning to realities within the environment in the hospital institutions"(22). The BHN theory encompasses all patients admitted to maternity units: laboring and puerperal women, newborns, and women undergoing gynecological surgery and receiving cancer treatment.

The results of the study show that the educational practice conducted with the nurses was an effective strategy to define the theoretical framework to be used in the maternity unit. Educational practices are processes that are based on collective dialogue among individuals who meet to transform, create and recreate reality ${ }^{(8)}$. Such processes are important strategies to transform reality, representing interactive processes that transform both nursing care practices and professionals ${ }^{(23)}$.

Educational practices stem from a learning process in which the educated and educators become true subjects of knowledge construction and reconstruction ${ }^{(8)}$. This should be an ongoing process in the nursing field, based on the assumption that nursing actions should be contemplated for the purpose of improving the quality of care.

The problematization methodology proposed by Paulo Freire ${ }^{(8)}$ allows subjects to become aware of, imagine, and visualize the problem, transforming their reality. Thus, combining dialogue and reflection with nursing practice can help professionals perceive the problems involved in their practice, creating hypotheses and searching for solutions to their problems, contributing to changing reality.

\section{Study limitations}

Limitations of this study include the small number of participants in the meetings, as only 15 nurses were involved in the instigation. This low level of participation can be explained by the fact that many nurses work double shifts, as well as by lack of professional interest and motivation. Furthermore, some nurses were working during the educational activity and could not be relieved of their duties.

\section{Contributions of the study}

The present study provided a space for reflection and discussion about the use of a framework to base the nursing practice in a maternity unit, providing nurses with the tools to choose a framework suited to their reality and the profile of patients. It is hoped that the study can contribute to discussions about the systematization of nursing care, which despite being a legal requirement and improving quality of care, has not been implemented in many institutions, while others still face difficulties in its operationalization.

\section{FINAL CONSIDERATIONS}

The present study resulted in the definition of a theoretical framework to be used in the maternity unit. The choice of the theory of basic human needs is an important step to effectively implement SNC. The results show that the nurses still need to deepen their knowledge about this theory to substantiate NP. Moreover, they must further develop some concepts (such as nursing, human beings, and environment), choose a diagnostic classification, and create NP instruments, among others.

The educational process brought important contributions, not only to the participating nurses, but to the entire nursing team. It helped foster discussion and reflections about the topic and highlighted the importance of defining a theoretical framework to guide their work processes.

The meetings were positively assessed; the nurses were satisfied with the initiative to implement SNC and mentioned that it was a great challenge that now seemed feasible. They suggested that the management could promote additional meetings with the nursing team to continue this process, considering the great relevance of the topic to professionals. Special mention also goes to the shortage of studies that address the issue of theoretical frameworks in maternal-infant nursing practice, which is not to say the nursing practices are not founded on nursing theories.

\section{FUNDING}

This study was funded by UNIEDU - the University Scholarship Program of Santa Catarina. 


\section{REFERENCES}

1. Souza MFG, Santos ADB, Monteiro AI. O processo de enfermagem na concepção de profissionais de Enfermagem de um hospital de ensino. Rev Bras Enferm [Internet]. 2013 [cited 2016 Aug 28];66(2):167-73. Available from: http://www.scielo.br/pdf/reben/ v66n2/03.pdf

2. Alcântara MR, Guedes-Silva D, Freiberger MF, Coelho MPPM. Teorias de enfermagem: a importância para a implementação da sistematização da assistência de enfermagem. Rev Cienc FAEMA[Internet]. 2011 [cited 2015 Sep 01];2(2):115-32. Available from: http://www.faema.edu.br/revistas/index.php/Revista-FAEMA/article/view/99/78

3. Conselho Federal de Enfermagem - COFEN. Resolução n. 358, de 15 de outubro de 2009. Dispõe sobre a Sistematização de Enfermagem e a implementação do Processo de Enfermagem em ambientes, públicos ou privados[Internet]. Diário Oficial da União 2009[cited 2016 Jun 05]. Available from: http://www.cofen.gov.br/resoluo-cofen-3582009_4384.html

4. Tavares TS, Castro AS, Figueiredo ARFF, Reis DC. Evaluation of the implementation of the systematic organization of nursing care in a pediatric ward. Rev Min Enferm [Internet]. 2013 [cited 2016 Aug 05];17(2):287-95. Available from: http://www.reme.org.br/ artigo/detalhes/650

5. Soares MI, Resck ZMR, Terra FS, Camelo SHH. Systematization of nursing care: challenges and features to nurses in the care management. Esc Anna Nery Rev Enferm [Internet]. 2015[cited 2016 Jun 04];9(1):47-53. Available from: http://www.scielo.br/pdf/ ean/v19n1/1414-8145-ean-19-01-0047.pdf

6. Massaroli R, Gue Martini J, Massaroli A, Lazzari DD, Oliveira SN, Canever BP. Nursing work in the intensive care unit and its interface with care systematization. Esc Anna Nery Rev Enferm [Internet]. 2015 [cited 2016 Aug 05];19(2):252-8. Available from: http://www.scielo.br/pdf/ean/v19n2/en_1414-8145-ean-19-02-0252.pdf

7. Granero-Molina J, Fernández-Sola C, Gonzales MHP, Aguilera-Manrique G, Mollinedo-Mallea J, Castro-Sánchez AM. Proceso de enfermería: ¿qué significa para las enfermeras de Santa Cruz (Bolivia)? Rev Esc Enferm USP [Internet]. 2012 [cited 2015 Dec 10];46(4):973-9. Available from: http://www.scielo.br/pdf/reeusp/v46n4/en_27.pdf

8. Freire P. Pedagogia da autonomia: saberes necessários à prática educativa. 39 a ed. São Paulo: Paz e Terra; 2009. 148p.

9. Brasil. Ministério da Saúde. Resolução 466/12 do Conselho Nacional de Saúde/MS, de 12 de dezembro de 2012, sobre Diretrizes e Normas Regulamentadoras de Pesquisa envolvendo seres humanos. [Internet]. Ministério da Saúde, 2013. [cited 2016 Sep 10]. Available from: http://conselho.saude.gov.br/resolucoes/2012/Reso466.pdf

10. Freire P. Conscientização: teoria e prática de libertação: uma introdução ao pensamento de Freire. $3^{a}$ ed. São Paulo: Centauro; 2008. 116p.

11. Morse JM, Field PA. Qualitative research methods for health professionals. 2nd ed. London: Sage; 1995.

12. Monticelli M. Aproximações culturais entre trabalhadoras de enfermagem e famílias no contexto do nascimento hospitalar: uma etnografia de alojamento conjunto [Tese]. Florianópolis: Universidade Federal de Santa Catarina, Programa de Pós-Graduação em Enfermagem. 2003.

13. Medeiros AL, Santos SR, Cabral RWL. Sistematização da assistência de enfermagem na perspectiva dos enfermeiros: uma abordagem metodológica na teoria fundamentada. Rev Gaúcha Enferm [Internet]. 2012 [cited 2016 Sep 10];33(3):174-81. Available from: http://www.scielo.br/pdf/rgenf/v33n3/23.pdf

14. Schaurich D, Crossetti MGO. Produção do conhecimento sobre teorias de enfermagem: análise de periódicos da área, 19982007. Esc Anna Nery Rev Enferm [Internet]. 2010[cited 2016 Sep 10];14(1):182-8. Available from: http://www.scielo.br/pdf/ean/ v14n1/v14n1a27

15. Huitzi-Egilegor JX, Elorza-Puyadena MI, Urkia-Etxabe JM, Asurabarrena-Iraola C. Implementation of the nursing process in a health area: models and assessment structures used. Rev Latino-Am Enfermagem [Internet]. 2014 [cited 2016 Sep 10];22(5):772-7. Available from: https://www.ncbi.nlm.nih.gov/pmc/articles/PMC4292680/

16. Karnick PM. The importance of defining theory in nursing: is there a common denominator? J Nurs Sci Q[Internet]. 2013 [cited 2016 Sep 10];26(1):29-30. Available from: http://nsq.sagepub.com/content/26/1/29.abstract

17. Porto AR, Thofehrn MB, Pai DD, Amestoy SC, Joner LR, Palma JS. Nursing theories and models that enhance professional practice. Rev Pesq: Cuid Fundam[Internet]. 2013[cited 2016 Aug 8];5(5):155-61. Available from: http://www.seer.unirio.br/index. $\mathrm{php/cuidadofundamental/article/view/1720}$

18. Souza NR, Costa BMB, Carneiro DCF. Systematization of nursing care: difficulties referred by nurses of a university hospital. J Nurs UFPE [Internet]. 2015[cited 2016 Sep 10];9(3):7104-10. Available from: http://www.revista.ufpe.br/revistaenfermagem/index.php/ revista/article/view/6337/pdf_7399

19. Maria MA, Quadros FAA, Grassi MFA. Sistematização da assistência de enfermagem em serviços de urgência e emergência: viabilidade de implantação. Rev Bras Enferm [Internet]. 2012[cited 2016 Aug 12];65(2):297-303. Available from: http://www. scielo.br/pdf/reben/v65n2/v65n2a15.pdf

20. Garcia TR. Sistematização da assistência de enfermagem: aspecto substantivo da prática profissional. Esc Anna Nery Rev Enferm 
[Internet]. 2016 [cited 2017 Jun 23];20(1):5-10. Available from: http://www.redalyc.org/pdf/1277/127744318001.pdf

21. Furtado LG, Nóbrega MML. Model of care in chronic disease: inclusion of a theory of nursing. Texto Contexto Enferm [Internet]. 2013[cited 2016 Aug 8];22(4):1197-204. Available from: http://www.scielo.br/pdf/tce/v22n4/en_39.pdf

22. Pires SMB, Méier MJ, Danski MTR. Fragmentos da trajetória pessoal e profissional de Wanda Horta: contribuições para a área da enfermagem. Hist Enferm Rev Eletron[Internet]. 2011[cited 2016 Sep 10];2(1):1-15. Available from: http://pesquisa.bvsalud.org/ enfermagem/resource/pt/bde-25617

23. Santos SV. Guia para prevenção e tratamento de lesões de pele em recém-nascidos internados em Unidade de Terapia Intensiva Neonatal: uma construção coletiva da equipe de enfermagem [Dissertação]. Florianópolis: Universidade Federal de Santa Catarina, Programa de Pós-Graduação em Enfermagem; 2014. 